\title{
EKSISTENSI PENGRAJIN PARANG DI SUMBAWA : OPTIMALISASI PENGGUNAAN STRATEGI PEMASARAN
}

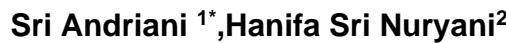 \\ ${ }^{1 *}$ Fakultas Ekonomi dan Bisnis Universitas Teknologi Sumbawa \\ 2Program Studi Manajemen dan Bisnis Universitas Teknologi Sumbawa
}

*Corresponding Author email: sri.andriani@uts.ac.id

Diterima
Bulan Juni 2020

Diterbitkan
Bulan Juli 2020

Keyword:
UMKM,
Pengrajin
Parang, Strategi
Pemasaran,
SWOT

\begin{tabular}{l} 
Abstrak \\
\hline Pertumbuhan Usaha Mikro Kecil dan Menengah (UMKM) di Indonesia saat ini \\
cenderung mengalami kenaikan dan memberikan kontribusi cukup besar dalam
\end{tabular} pembangunan. Di sisi lain, hal ini menyebabkan tingkat persaingan di sektor UMKM juga akan semakin meningkat. Salah satu UMKM yang masih ada di Indonesia Timur seperti Kabupaten Sumbawa salah satunya adalah pengrajin parang. Tujuan penelitian ini adalah 1) Mengidentifikasi faktor-faktor internal dan eksternal yang dihadapi pengrajin parang di Desa Batu Alang. 2) Merumuskan alternatif strategi pemasaran pengrajin parang di Desa Batu Alang yang diperoleh berdasarkan hasil analisis. 3) Menentukan prioritas strategi pemasaran yang tepat bagi pengrajin parang di Desa Batu Alang untuk menjalankan usahanya. Penelitian ini dilaksanakan di Desa Batu Alang Kecamatan Moyo Hulu menggunakan metode deskriptif dan pengumpulan datanya dilakukan dengan teknik observasi dan survey. Penentuan responden dilakukan dengan teknik survey. Hasil yang diperoleh, pada matriks IFE, rata-rata nilai IFE adalah 3,012 sedangkan matriks EFE sebesar 2,704. Hasil tersebut menempatkan pengrajin parang di desa Batu Alang berada pada sel IV yang disebut strategi tumbuh dan membangun. Pada posisi ini, untuk mempertahankan eksistensinya dimungkinkan untuk melakukan strategi intensif dan strategi integratif.

\section{PENDAHULUAN}

Fokus pada pelanggan dan sangat berkomitmen terhadap pemasaran menjadi salah satu kesamaan yang dimiliki oleh perusahaan sukses saat ini. (Kotler dan Amstrong, 2011). Hal ini berlaku bagi semua jenis perusahaan baik skala global maupun perusahaan yang termasuk dalam kategori Usaha Mikro, Kecil, dan Menengah (UMKM). Menurut Ramli (2010), keunggulan UMKM di Indonesia berkembang pesat dan memberikan kontribusi besar dalam pembangunan. Hal ini dapat dilihat dari beberapa indikator, yaitu semakin bertambahnya jumlah UMKM, penyerapan tenaga kerja, sumbangan terhadap Produk Domestik Bruto (PDB). Salah satu UMKM yang masih ada sampai saat ini di Sumbawa adalah pengrajin parang.

Data dari Badan Pusat Statistik menyebutkan bahwa sentra pengrajin parang yang masuk dalam kategori Industri Logam, Mesin dan Perekayasaan, pada tahun 2014 terdapat 9 sentra industri, 86 unit usaha dan 322 tenaga kerja. Masih bisa dikatakan rendah dibandingkan dengan sentra industri lainnya. Bahkan pengrajin parang sudah mulai terancam eksistensinya termasuk di Desa Batu Alang Moyo Hulu, Sumbawa. Sehingga, industri yang berskala kecil (UMKM) juga harus menerapkan strategi pemasaran yang tepat terutama produk yang bersifat hand made yang membutuhkan ketelitian dan waktu yang cukup lama seperti halnya pengrajin parang.

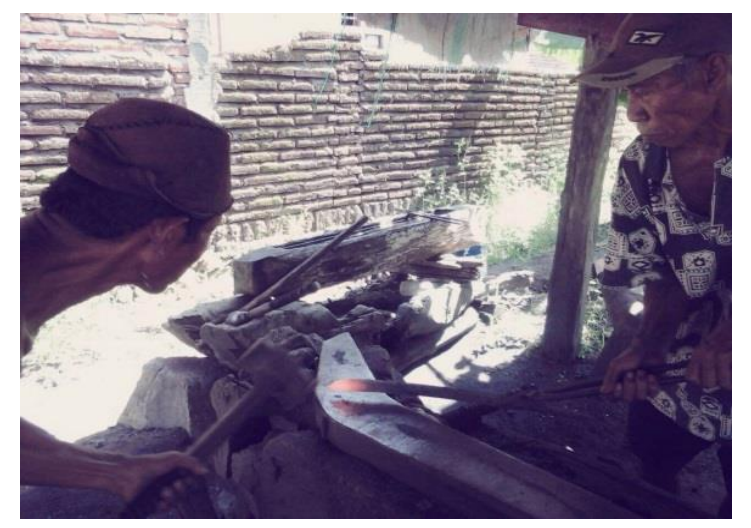

Gambar 1. Proses Pembuatan Parang oleh Pengrajin Parang di Desa Batu Alang

Menurut Buffet dalam Hagstrom (2005), yang dinginkan oleh pebisnis/pelaku usaha adalah berada di bisnis yang dipahami, dijalankan oleh orangorang yang disukai, dan dihargai secara baik dibandingkan prospek mereka di masa depan. Terkait konsep pemasaran, seluruh model akan terkait dengan pemasaran strategis (Aghazade, 2015). Untuk itu, perlu ada strategi yang cukup baik untuk mempertahankan eksistensi pelaku UMKM di Indonesia khususnya pengrajin parang. Sehingga 
proses penciptaan lapangan kerja baru dan berkurangnya angka kemiskinan dapat terwujud.

\section{LANDASAN TEORI}

\section{Pemasaran}

Pemasaran memiliki peran yang penting dalam meningkatkan kinerja perusahaan baik secara finansial maupun non finansial. Menurut Khotler (2008), pemasaran adalah terciptanya pemenuhan kebutuhan dan keingan manusia baik secara kelompok maupun individu melalui sistem manajerial yang menghasilkan penciptaan, penawaran dan pertukaran produk-produk yang bernilai.).

\section{Strategi Pemasaran}

The concept of marketing is inherently simple business success through a process of understanding and meeting customer needs (Drummond et al, 2008). Sehingga manajer pemasaran harus mampu memahami perubahan perilaku dan kebutuhan pelanggan. Menurut Khotler (2008) strategi pemasaran ada tiga yaitu segmentation, targeting, dan positioning.

\section{Bauran Pemasaran}

Sebagai seorang manajer pemasaran, bauran pemasaran adalah salah satu hal penting yang perlu diperhatikan dan dikelola dengan baik. Bauran pemasaran adalah seperangkat alat pemasaran yang sering juga disebut sebagai empat Ps- the product, its price, place dan promotion (Baker, J. Michael, 2003). Hal ini dijelaskan dalam gambar di bawah ini.

Menurut Khotler (2008) bauran pemasaran digunakan untuk melakukan pembentukan karakteristik barang/produk yang ditawarkan kepada pelanggan. Tjiptono (2008) menyatakan bahwa unsur-unsur bauran pemasaran terdiri dari : Product (produk), Price (harga), Promotion (promosi), Place (tempat), People (manusia), dan Process (proses).

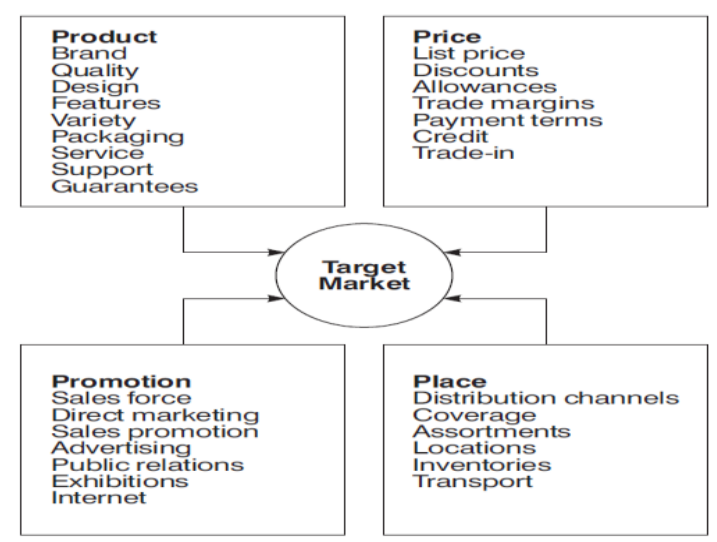

Gambar 2. Unsur-Unsur Bauran Pemasaran

Sumber : (Baker, J. Michael, 2003)

Analisis SWOT
Analisis SWOT telah banyak dilakukan di penelitian sebelumnya. Karena dengan analisis ini perusahaan dapat mengidentifikasi kekuatan, kelemahan, peluang dan ancaman serta merumuskan startegi yang sebaiknya diimplemantasikan. Penelitian yang dilakukan oleh Wibowo et al (2014) memberikan kesimpulan bahwa penggunaan strategi pemasaran secara efektif menunjukkan adanya peningkatan total penjualan dari tahun ke tahun dan dijadikan sebagai acuan efektifitas strategi pemasaran dalam persaingan antar perusahaan batik.

Matriks SWOT memiliki kelebihan dan kelemahan diantaranya, 1) strategi dapat diperiksa secara berurutan atau bersamaan; 2) tidak ada batas jumlah strategi yang dapat diperiksa atau dievaluasi; dan 3) membutuhkan ketelitian dalam memadukan faktor-faktor eksternal dan internal yang terkait dalam proses keputusan. (David, 2010)

Matrik ini merupakan matching tool yang penting untuk membantu para manajer mengembangkan empat tipe strategi (Purwanto dalam Ningrum, 2010). Keempat strategi itu adalah Strategi SO (Strengths Opportunities), Strategi WO (Weaknesses Opportunities), Strategi ST (Strengths Threats) dan Strategi WT (Weaknesses Threats)

\section{Matriks Quantitative Strategic Palnning (QSPM)}

Teknik QSPM dirancang untuk menentukan kemenarikan relatif dan mengevaluasi pilihanpilihan strategi alternatif yang dapat dilaksanakan secara objektif, berdasarkan faktor-faktor sukses internal dan eksternal yang telah diidentifikasikan pada matriks EFE dan IFE sebelumnya. Teknik ini secara jelas menunjukkan strategi alternatif yang paling baik untuk dipilih. Purwanto dalam Ningrum (2010)

\section{MATODE PENELITIAN}

\section{Jenis Penelitian}

Pada dasarnya peneliti mengukur keberhasilan pemasaran dari peringkat produk baru, meningkatkan kesadaran merek, tingkat kesukaan merek, keunikan produk, daya beli, dan kepuasan pelanggan. (Smith and Albaum, 2013). Penelitian ini merupakan penelitian deskriptif kualitatif, menganalisis strategi pemasaran yang digunakan kemudian merumuskan strategi baru dari hasil wawancara/survey dengan responden. Moleong (2008) menjelaskan bahwa penelitian kualitatif adalah penelitian yang bermaksud untuk memahami tentang apa yang dialami oleh subyek penelitian (misalnya perilaku, persepsi, motivasi, dan tindakan) secara holistic dan dengan cara deskripsi dalam bentuk kata-kata dan bahasa pada suatu konteks khusus yang alamiah dan dengan memanfaatkan berbagai metode alamiah. 
Teknik Pengumpulan dan Analisis Data

Teknik Pengumpulan Data

Teknik yang digunakan dalam mengumpulkan data adalah :

1. Penelitian Lapangan (Field Research)

Yaitu penelitian yang dilakukan pada usaha bersangkutan untuk memperoleh data yang berhubungan dengan penulisan dengan cara :

a. Observasi, yaitu suatu bentuk penelitian yang dilakukan penulis dengan pengamatan baik berhadapan langsung maupun secara tidak langsung seperti memberikan daftar pertanyaan untuk dijawab.

b. Wawancara, yaitu penelitian yang dilakukan dengan jalan mengumpulkan dokumen-dokumen yang berhubungan dengan penelitian ini.

2. Penelitian Kepustakaan

Yaitu penelitian yang dilakukan dengan membaca beberapa buku literatur-literatur, mengumpulkan dokumen, arsip maupun catatan penting organisasi yang berhubungan dengan permasalahan penulisan penelitian dan selanjutnya diolah kembali.

\section{HASIL DAN PEMBAHASAN}

Secara umum pengrajin parang di desa Batu Alang mulai ada sekitar tahun 1990-an secara turun temurun. Berdasarkan pengamatan yang dilakukan, terdapat 6 tempat pengrajin parang yang ada di Desa Batu Alang. Bagi pengrajin yang tidak memiliki tempat pembuatan parang, maka diberlakukan sistem sewa tempat. Pengrajin parang di desa ini tidak secara penuh berprofesi sebagai pengrajin parang, petani dan peternak merupakan profesi lain yang digeluti secara umum masyarakat setempat.

Kendala utama dalam proses pembuatan adalah terlalu mengandalkan tenaga manusia sehingga waktu yang dibutuhkan cukup lama berkisar 2-3 hari tergantung jenis besi yang dipilih pelanggan dan dana yang diberikan diawal.

\section{Strategi Pemasaran Pengrajin Parang di Desa Batu Alang

Strategi pemasaran yang saat ini dijalankan oleh pengrajin parang di desa Batu Alang adalah product variety marketing yang mengikuti selera pasar (pelanggan) dengan menghasilkan parang yang beragam mulai dari ukuran, model gagang dan kualitas. Pengelompokan pasar menjadi beberapa kelompok :

a. Kelas menengah (pengusaha)

b. Kelas bawah (petani)

\section{Targeting}

UKM ini fokus pada usaha membuat parang dengan beberapa ukuran dan model seperti pisau, parang mini, parang sedang, parang besar, parang panjang sedang, parang panjang besar dan sabit.

\section{Positioning}

Sampai saat ini parang yang dihasilkan oleh pengrajin parang di desa Batu Alang cukup bagus dan memiliki penilaian yang baik dari pelanggan. Namun, model yang ditawarkan masih belum beragam (tidak diversifikasi)

\section{Bauran Pemasaran Produk}

a. Product (produk)

Pengrajin parang merupakan salah satu UKM yang menghasilkan parang yang diproduksi secara sederhana menggunakan peralatan yang sederhana. Ada beberapa jenis parang yang dihasilkan yaitu :

1. Parang Kecil

2. Parang Panjang Sedang

3. Parang Sedang

4. Parang Panjang Besar

5. Parang Besar

b. Price (harga)

Harga yang ditawarkan juga relatif terjangkau untuk semua segmen pasar dimana penentuan harga didasarkan pada kualitas dan harga bahan baku. Harga dapat dilihat pada tabel 1 di bawah ini.

Tabel 1. Harga Jual Parang di Desa Batu Alang

\begin{tabular}{|l|r|}
\hline \multicolumn{1}{|c|}{ Jenis Parang } & Harga (Rp) \\
\hline Parang Mini & 175.000 \\
\hline Parang Sedang & 175.000 \\
\hline Parang Besar & 250.000 \\
\hline Parang Panjang Sedang & 200.000 \\
\hline Parang Panjang Besar & 250.000 \\
\hline
\end{tabular}

c. Promotion (promosi)

Promosi dilakukan dengan cara mouth to mouth pelanggan yang sebelumnya telah membeli parang di desa Batu Alang. Para pengrajin hanya mengandalkan kepercayaan dari pelanggan serta membina dan mempertahankan hubungan baik dengan pelanggan dengan harapan pelanggan puas dan menceritakan hal positif kepada calon pelanggan.

d. Place (tempat)

Berdasarkan pengamatan yang dilakukan, terdapat 6 tempat pengrajin parang yang semuanya terletak di Desa Batu Alang.

e. People (sumber daya manusia)

Pengrajin parang di desa Batu Alang tidak memiliki karyawan, pemilik sekaligus sebagai pengrajin parang.

f. Process (proses)

Proses pembuatan parang berdasarkan pesanan (job by order). Hal ini dikarenakan kebutuhan masyarakat akan parang belum 
terlalu tinggi, sehingga produksi parang tidak dilakukan dalam jumlah banyak.

g. Physical Evidence (bukti fisik)

Dalam menjalankan usahanya, pengrajin parang di desa Batu Alang memiliki tempat bengkel kerja, mulai dari tempat pembakaran besi sampai pembentukan parang.

\section{Analisis Lingkungan Usaha}

Pada tahapan ini, dilakukan identifikasi kondisi lingkungan usaha baik secara internal maupun eksternal yang mempengaruhi proses pencapaian tujuan usaha.

\section{Analisis Lingkungan Internal}

Analisis IFE menggambarkan analisis lingkungan perusahaan secara internal berupa kekuatan dan kelemahan yang dimiliki perusahaan. Matriks IFE juga memberikan gambaran hubungan dan evaluasi antar bidang-bidang fungsional di dalam perusahaan.Berikut ditampilkan matriks IFE dari pengrajin parang di desa Batu Alang.

Tabel 2. Matriks IFE Pengrajin Parang di Desa Batu Alang

\begin{tabular}{|c|c|c|c|c|}
\hline No & Internal Faktor & Bobot & Rating & Skor \\
\hline \multicolumn{5}{|c|}{ Kekuatan ((Strengths) } \\
\hline 1 & \begin{tabular}{lr}
\multicolumn{2}{l}{ Memiliki prospek } \\
usaha yang baik \\
dan ramah \\
lingkungan
\end{tabular} & 0,146 & 1,833 & 0,268 \\
\hline 2 & $\begin{array}{l}\text { Pengrajin memiliki } \\
\text { pengalaman yang } \\
\text { baik dalam teknik } \\
\text { membuat parang }\end{array}$ & 0,088 & 3,500 & 0,308 \\
\hline 3 & $\begin{array}{l}\text { Memiliki produk } \\
\text { yang bernilai } \\
\text { ekonomis }\end{array}$ & 0,111 & 3,000 & 0,333 \\
\hline 4 & $\begin{array}{l}\text { Lokasi tempat } \\
\text { kerja milik sendiri }\end{array}$ & 0,065 & 4,000 & 0,260 \\
\hline \multicolumn{5}{|c|}{ Kelemahan (Weaknesses) } \\
\hline 5 & $\begin{array}{l}\text { Masih melakukan } \\
\text { kegiatan secara } \\
\text { mandiri dengan } \\
\text { peralatan } \\
\text { sederhana }\end{array}$ & 0,065 & 4,000 & 0,260 \\
\hline 6 & $\begin{array}{l}\text { Rendahnya } \\
\text { pendidikan } \\
\text { pengrajin }\end{array}$ & 0,096 & 3,167 & 0,304 \\
\hline 7 & $\begin{array}{l}\text { Tidak dilakukan } \\
\text { promosi/periklanan }\end{array}$ & 0,096 & 3,333 & 0,320 \\
\hline 8 & $\begin{array}{l}\text { Modal kerja yang } \\
\text { terbatas }\end{array}$ & 0,097 & 3,333 & 0,323 \\
\hline 9 & $\begin{array}{ll}\text { Pekerja } & \text { gagap } \\
\text { teknologi } & \end{array}$ & 0,103 & 3,167 & 0,326 \\
\hline \multirow[t]{2}{*}{10} & $\begin{array}{l}\text { Model produk yang } \\
\text { kurang inovatif }\end{array}$ & 0,133 & 2,333 & 0,310 \\
\hline & & 1,000 & & 3,012 \\
\hline
\end{tabular}

Sumber : Diolah oleh penulis

Tabel di atas menggambarkan tentang kondisi internal perusahaan dilihat dari matriks IFA. Dari segi kekuatan, memiliki produk yang bernilai ekonomis memperoleh skor tertinggi yaitu sebesar 3,333. Pada urutan kedua, Pengrajin memiliki pengalaman yang baik dalam teknik membuat parang mendapat skor sebesar 3, 308. Kemudian urutan ketiga dengan skor 0,268 adalah memiliki prospek usaha yang baik dan ramah lingkungan. Dan terakhir di urutan ke empat, lokasi tempat kerja milik sendiri memperoleh skor sebesar 0,260 .

Sedangkan dari segi kelemahan, urutan pertama adalah pekerja gagap teknologi dengan skor 0,326. Berikutnya diurutan kedua dengan skor 0,323 , modal kerja yang terbatas. Urutan ketiga, tidak dilakukan promosi/periklanan dengan skor 3,320. Selanjutnya urutan keempat, model produk yang kurang inovatif dengan skor 0,310 . Urutan kelima adalah rendahnya Pendidikan pengrajin dengan skor 0,304 dan terakhir urutan keenam dengan skor 0,260 adalah masih melakukan kegiatan secara mandiri dengan peralatan sederhana. Penggabungan kedua faktor internal tersebut menghasilkan skor rata-rata 3,012.

\section{Analisis Lingkungan Eksternal}

Berbeda dengan matriks IFE, matriks EFE menganalisis tentang kondisi ekternal perusahaan dengan melihat peluang dan ancaman yang terjadi bagi perusahaan. Dengan menggunakan cara perhitungan yang sama dengan matrik IFE, berikut ditampilkan matrik EFE pengrajin parang di desa Batu Alang.

Tabel 3. Matriks EFE Pengrajin Parang di Desa Batu Alang

\begin{tabular}{|c|c|c|c|c|}
\hline No & Eksternal Faktor & Bobot & Rating & Skor \\
\hline \multicolumn{5}{|c|}{ Peluang (Opportunities) } \\
\hline 1 & $\begin{array}{l}\text { Meningkatnya } \\
\text { perekonomian Negara } \\
\text { dengan program UKM } \\
\text { mandiri }\end{array}$ & 0,113 & 2,333 & 0,264 \\
\hline 2 & $\begin{array}{ll}\text { Adanya } & \text { program } \\
\text { pemerintah } & \text { provinsi } \\
\text { "Visit } & \text { Lombok } \\
\text { Sumbawa" } & \\
\end{array}$ & 0,122 & 2,333 & 0,285 \\
\hline 3 & $\begin{array}{l}\text { Mulai banyak turis } \\
\text { asing yang berkunjung } \\
\text { ke Sumbawa }\end{array}$ & 0,119 & 2,333 & 0,278 \\
\hline 4 & $\begin{array}{l}\text { Lokasi yang dekat } \\
\text { dengan kampus UTS }\end{array}$ & 0,058 & 4,000 & 0,232 \\
\hline 5 & Kemajuan teknologi & 0,134 & 2,000 & 0,268 \\
\hline 6 & $\begin{array}{ll}\text { Lokasi dekat } & \text { dengan } \\
\text { Sumbawa } & \text { Techno } \\
\text { Park } & \end{array}$ & 0,081 & 3,333 & 0,270 \\
\hline \multicolumn{5}{|c|}{ Ancaman (Threats) } \\
\hline 7 & $\begin{array}{l}\text { Tingkat daya beli } \\
\text { masyarakat } \\
\text { rendah }\end{array}$ & 0,108 & 2,667 & 0,288 \\
\hline 8 & $\begin{array}{l}\text { Semakin langka } \\
\text { persediaan bahan } \\
\text { baku yang baik }\end{array}$ & 0,108 & 2,667 & 0,288 \\
\hline 9 & $\begin{array}{l}\text { Semakin } \\
\text { meningkatnya produk } \\
\text { substitusi }\end{array}$ & 0,088 & 3,167 & 0,279 \\
\hline \multirow[t]{2}{*}{10} & \begin{tabular}{lr} 
Banyak & \multicolumn{2}{c}{ beredar } \\
produk & sejenis dari \\
pesaing &
\end{tabular} & 0,069 & 3,667 & 0,253 \\
\hline & & 1,000 & & 2,704 \\
\hline
\end{tabular}

Sumber : Diolah oleh penulis

Matrik EFE di atas terlihat bahwa adanya program pemerintah provinsi "Visit Lombok Sumbawa" dengan skor 2,285 berada pada urutan yang sangat penting dalam memberikan peluang bagi pengrajin parang di desa Batu Alang. Mulai banyak turis asing yang berkunjung ke Sumbawa berada pada urutan kedua dengan skor 2,278. Diurutan ketiga dengan skor 2,270 adalah Lokasi dekat dengan Sumbawa Techno Park. 
Selanjutnya di urutan ke empat dan kelima masingmasing dengan skor 2,268 dan 2,264 adalah adanya kemajuan teknologi dan meningkatnya perekonomian negara dengan program UKM mandiri. Dan urutan terakhir adalah lokasi yang dekat dengan kampus UTS dengan skor 0,232.

Bagi pengrajin parang di desa Batu Alang, terdapat dua ancaman terbesar yang sangat penting yaitu tingkat daya beli masyarakat masih rendah dan semakin langka persediaan bahan baku yang baik yang mendapat skor yang sama sebesar 0,288. Diurutan ketiga dengan skor 2,278 adalah semakin meningkatnya produk substitusi. Dan urutan terakhir ancamannya adalah banyak beredar produk sejenis dari pesaing dengan skor 0,253 . Gabungan dari kedua faktor di atas rata-rata adalah 2,704.

\section{Analisis Lingkungan Internal dan Eksternal}

Analisis lingkungan eksternal dan internal dilakukan dengan tujuan untuk menentukan strategi yang tepat untuk diterapkan oleh suatu perusahaan. Apalagi di era digital seperti saat ini, persaingan sudah semakin meningkat signifikan. Perhitungan dilakukan dengan cara memasukkan rata-rata nilai matrik IFE dan matrik EFE untuk kemudian dimasukkan dalam sebuah sel-sel disesuaikan dengan nilai tersebut. Pada matriks IFE, rata-rata nilai IFE adalah 3,012 sedangkan matriks EFE sebesar 2,704. Hasil tersebut menempatkan pengrajin parang di desa Batu Alang berada pada sel IV yang disebut strategi Tumbuh dan Membangun. Pada posisi ini memungkinkan melakukan strategi intensif dan strategi integratif. Strategi intensif dapat dilakukan melalui penetrasi pasar dengan memperluas market share melalui usaha pemasaran/promosi, pengambangan pasar dengan memperluas pangsa pasar secara geografis merupakan wilayah baru dan pengembangan produk dengan cara memodifikasi produk. Strategi ini umum digunakan oleh perusahaan yang produknya mengalami kejenuhan. Selain itu juga pada sel IV terdapat strategi integratif yaitu integrasi ke depan, integrasi ke belakang dan integrasi horizontal.

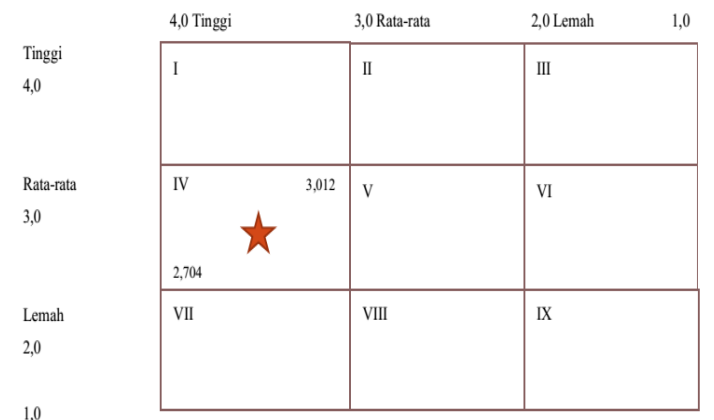

Gambar 3. Matriks IE Pengrajin Parang di Desa

$\begin{array}{cl}\text { Keterangan } & : \\ \text { Vertikal } & \text { : Total Skor IFE } \\ \text { Horizontal } & \text { : Total Skor EFE }\end{array}$

\section{Analisis Matriks SWOT}

Matriks SWOT merupakan pengembangan dari matriks IE yang dilakukan dengan tujuan untuk menemukan alternatif strategi yang dirumuskan setelah menganalisis kondisi internal dan eksternal perusahaan. Terdapat 4 macam strategi utama yang disarankan yaitu, strategi SO, ST, WO, dan WT. Berikut diuraikan dalam matriks SWOT pengrajin parang di desa Batu Alang

Tabel 4. Matriks SWOT Pengrajin Parang di Desa Batu Alang

\begin{tabular}{|c|c|c|}
\hline & Kekuatan (Strengths) : & Kelemahan (Weaknesses) : \\
\hline Peluang (Opportunities): & $\begin{array}{l}\text { Strategi } \mathrm{S}-\mathbf{O} \\
\begin{aligned} & \text { 1. } \text { Memperluas pangsa } \\
& \text { pasar }(\mathrm{S} 1, \mathrm{~S} 3, \mathrm{O} 1, \mathrm{O} 2, \\
& \mathrm{O}, \mathrm{O}, \mathrm{O}, \mathrm{O} \text { ) } \\
& \text { 2. } \text { Mengadakan kerjasama } \\
& \text { dengan instansi } \\
& \text { pendidikan terutama } \\
& \text { tentang pendampingan } \\
& \text { UKM. }(\mathrm{S} 1, \mathrm{~S} 2, \mathrm{O} 4, \mathrm{O} 6)\end{aligned}\end{array}$ & \begin{tabular}{|rl} 
Strategi W-O \\
1. & Memperkuat modal \\
& melalui kerjasama \\
& dengan instansi \\
& pemerintah maupun \\
& swasta $(\mathrm{O} 1, \mathrm{~W} 4)$ \\
2. & Meningkatkan promosi \\
& (W3, W5, O2, O3)
\end{tabular} \\
\hline Ancaman (Threats) : & $\begin{array}{ll}\text { Strategi S- T } \\
\text { 1. } & \text { Menetapkan strategi } \\
& \text { harga pasar untuk } \\
& \text { menghadapi persaingan } \\
& (\mathrm{S} 1, \mathrm{~S} 2, \mathrm{~S} 3, \mathrm{~T} 1, \mathrm{~T} 2) \\
\text { 2. } & \text { Meningkatkan } \\
& \text { diversifikasi jenis produk } \\
\text { dan kualitas produk ( } \mathrm{S} 2, \\
\mathrm{~S} 4, \mathrm{~T} 3, \mathrm{~T} 4)\end{array}$ & \begin{tabular}{|rl} 
Strategi W - T \\
1. & Meningkatkan \\
& penguasaan teknologi \\
& $(\mathrm{T} 2, \mathrm{~T} 5, \mathrm{~W} 4)$ \\
2. & Meningkatkan kreativitas \\
& $\mathrm{SDM}(\mathrm{T} 2, \mathrm{~T} 5, \mathrm{~W} 1, \mathrm{~W} 3)$
\end{tabular} \\
\hline
\end{tabular}

Sumber : data diolah penulis

Beberapa alternatif strategi yang ditawarkan dari analisis matriks SWOT di atas adalah sebagai berikut :

1. Memperluas pangsa pasar (S1, S3, O1, O2, O3, O4, O6)

2. Mengadakan kerjasama dengan instansi pendidikan terutama tentang pendampingan UKM. (S1, S2, O4, O6)

3. Menetapkan strategi harga pasar untuk menghadapi persaingan (S1, S2, S3, T1, T2)

4. Meningkatkan diversifikasi jenis produk dan kualitas produk (S2, S4, T3, T4)

5. Memperkuat modal melalui kerjasama dengan instansi pemerintah maupun swasta (O1, W4)

6. Meningkatkan promosi (W3, W5, O2, O3)

7. Meningkatkan penguasaan teknologi (T2, T5, W4)

8. Meningkatkan kreativitas SDM (T2, T5, W1, W3)

\section{Analisis Matriks Quantitative Strategic Planning (QSPM)}

Tahapan akhir yang perlu dilakukan dalam menganalisis formulasi strategi adalah memilih alternatif strategi yang sebaiknya lebih diutamakan untuk diterapkan diperusahaan tersebut. Hal ini dapat dilakukan dengan menggunakan Matriks Quantitative Strategic Planning (QSPM). Pemilihan alternatif dilakukan dengan melakukan 
penilaian terhadap alternatif yang telah ditawarkan sebelumnya disesuaikan dengan kuisioner yang telah diisi oleh responden. Berikut adalah seluruh pemeringkatan alternatif yang dihasilkan menggunakan perumusan QSPM.

Tabel 5. Pemeringkatan Strategi Menggunakan QSPM

\begin{tabular}{|c|l|c|}
\hline Peringkat & \multicolumn{1}{|c|}{ Strategi } & $\begin{array}{c}\text { Total } \text { Attractiveness } \\
\text { Score }\end{array}$ \\
\hline 1 & $\begin{array}{l}\text { Meningkatkan diversifikasi jenis produk dan kualitas produk } \\
(\text { ST-2) }\end{array}$ & 6,674 \\
\hline 2 & Meningkatkan promosi (WO-2) & 6,506 \\
\hline 3 & Meningkatkan kreativitas SDM (TW-2) & 6,438 \\
\hline 4 & $\begin{array}{l}\text { Mengadakan kerjasama dengan instansi pendidikan terutama } \\
\text { tentang pendampingan UKM. (SO-2) }\end{array}$ & 6,372 \\
\hline 5 & Meningkatkan penguasaan teknologi (TW-2) & 6,208 \\
\hline 6 & $\begin{array}{l}\text { Memperkuat modal melalui kerjasama dengan instansi } \\
\text { pemerintah maupun swasta (WO-1) }\end{array}$ & 6,130 \\
\hline 7 & Memperluas pangsa pasar (SO-1) & 6,055 \\
\hline 8 & $\begin{array}{l}\text { Menetapkan strategi harga pasar untuk menghadapi persaingan } \\
\text { (ST-1) }\end{array}$ & 5,479 \\
\hline
\end{tabular}

Sumber : data diolah penulis

Dari tabel di atas, strategi yang sebaiknya diutamakan untuk dilakukan sesuai dengan analisis internal dan eksternal perusahaan adalah strategi Strengths Threats 1, meningkatkan diversifikasi jenis produk dan kualitas produk. Strategi ini daharapkan dapat memberikan dampak yang positif bagi perkembangan usaha pengrajin parang di desa Batu Alang.

\section{Kesimpulan}

\section{Kesimpulan}

Pemerintah daerah dan provinsi berupaya memberikan ruang bagi pelaku UMKM untuk terus mengembangkan diri. Salah satunya melalui pengembagnan pariwisata di setiap daerah di Provinsi NTB. Promosi wisata Lombok Sumbawa sudah banyak dilakukan melalui berbagai media. Bahkan keberadaan Sumbawa Techno Park sebetulnya dapat dijadikan peluang oleh pelaku UMKM.

Menggunakan analisis SWOT ditemukan bahwa pengrajin parang di Desa Vatu Alang Kec. Moyo Hulu berada pada sel IV yang disebut strategi Tumbuh dan Membangun. Pada posisi ini memungkinkan melakukan strategi intensif dan strategi integratif. Matrik QSPM menerangkan bahwa untuk meminimalisir kelemahan dan ancaman, pengrajin parang di Desa Vatu Alang Kec. Moyo Hulu dapat menggunakan strategi meningkatkan diversifikasi jenis produk dan kualitas produk.

\section{REFERENSI}

Aghazadeh, Hashem. 2015. Strategic Marketing Management : Achieving Superior Business Performance Throgh Intelligent Marketing Strategy. Procedia-Social and Behavioral Science.

Anas, Titik., dkk. 2015. Pemetaan dan Strategi Peningkatan Daya Saing UMKM dalam Menghadapi MEA 2015 dan Pasca MEA 2025. Bank Indonesia.

Artati, Rosmeilia Yeni. 2007. Evaluasi Strategi Pemasaran Pada Lembaga Bimbingan Belajar Primagama Cabang Sutoyo Semarang. Tesis. UNDIP.Semarang

Baker, Michale. J. 2003. The Marketing Book Fith Edition. Butterworth Heinemann.

Badan Pusat Statistik. 2015. Sumbawa Dalam Angka 2015. http://www.sumbawakab.bps.go.id (akses tanggal 26 Mei 2016)

David, F.R. 2004. Manajemen Strategi : KonsepKonsep. Edisi Sembilan. Indeks, Jakarta

Drummond, Graeme., Ensor, Jhon., and Asford, Ruth. 2008. Strategic Management Project and Control. Elsevier.

Hagstrom, Robert G. 2005. "The Warrent Buffett Way Second Edition”. Ney Jersey : John Wiley \& Sons, Inc.

Kompasiana. 2015. "Problematika Apa Saja yang Dihadapi UMKM di Indonesia".

(http://www.kompasiana.com/ussisa/problemati ka-apa-saja-yang-dihadapiumkm-di-indonesia). Akses tanggal 10 September 2017.

Kotler, P. Gary, A. 2008. "Prinsip-prinsip Pemasaran”. Jakarta : Erlangga.

Kotler, Philip dan Amstrong, Gary. 2011. "Principles of Marketing”. Ney Jersey : Person Prentice Hall.

Moleong, Lexy J. (2008). “Metodologi Penelitian Kualitatif”. Bandung: Remaja Rosdakarya.

Ningrum, Putri Ardhanareswari Hamardika. 2010. Analisis Strategi Pemasaran Usaha Jasa Pembuatan dan Perbaikan Furniture UD.Suryani Furniture, Bogor, Jawa Barat. Skripsi. Bogor : Fakultas Ekonomi dan Manajemen Institut Pertanian Bogor.

Pearce, J.A. dan R.B. Robbinson. 2008. Manajemen Strategi:Formulasi, Implementasi, dan Pengendalian. Jakarta : Salemba Empat.

Rahmat, Reny Maulidia. 2012. Analisis Strategi Pemasaran pada PT. Koko Jaya Prima Makassar. Makassar : Skripsi. Fakultas Ekonomi dan Bisnis Universitas Hasanuddin.

Ramli, N. 2010. Keberadaan UMKM. Republika Online. 2010.

Smith, Scott M. dan Albaum, Gerald M. 2013. "Basic Marketing Research, Building Youyr Survey. United States of America : Qualtrics Labs Inc. 
Tjiptono, F. 2008. “Strategi Pemasaran”. Andi. Yogyakarta.

Umar, H. 2008. "Manajemen Strategic in Action". PT. Gramedia Pustaka Utama. Jakarta.
Wibowo,dkk. 2015. “Analisis Strategi Pemasaran untuk Meningkatkan Daya Saing UMKM (Studi Kasus pada Batik Diajeng Solo) ”. Jurnal Administrasi Bisnis Universitas Brawijaya Volume 9 Nomor 1 